\title{
The Impact of Islamic Attributes of Destination on Destination Loyalty via the Mediating Effect of Tourist Satisfaction
}

\author{
Ibrahim Bazazo $^{1}$, Tariq Elyas ${ }^{2}$, Loay Awawdeh ${ }^{1}$, Myada Faroun $^{1} \&$ Sa'ad Qawasmeh ${ }^{1}$ \\ ${ }^{1}$ Department of Tourism Management, Faculty of Tourism and Hospitality, The University of Jordan, Aqaba, Jordan \\ ${ }^{2}$ English Language Institute, King Abdulaziz University, Jeddah, Saudi Arabia \\ Correspondence: Ibrahim Bazazo, Department of Tourism Management, Faculty of Tourism and Hospitality, The \\ University of Jordan, Aqaba, Jordan. Tel: 962-3-209-0450. E-mail: i.bazazo@ju.edu.jo
}

Received: June 15, 2017

Accepted: June 22, 2017

Online Published: June 27, 2017

doi:10.5430/ijba.v8n4p65

URL: https://doi.org/10.5430/ijba.v8n4p65

\begin{abstract}
This study quantifies the associations among Islamic attributes of destination, tourist satisfaction, and destination loyalty. Islamic attributes of destination consists of four dimensions namely worship facilities, halalness, alcohol \& gambling free, and Islamic morality. A survey instrument is used to examine the relationships in the proposed model by employing SEM technique. The collected primary data $(n=243)$ from tourists in Aqaba city located in Jordan is conducted to test the relationship between exogenous and endogenous construct expressed in the proposed structural model. The findings revealed that Islamic attributes of destination directly and tourists' satisfactions have significant impact on destination loyalty, besides tourists' satisfaction has significant impact on tourists' destination loyalty. However, as the coefficient of determination $\left(\mathrm{R}^{2}\right)$ for the research endogenous variables for tourists' satisfaction, and tourists' destination loyalty were 0.41 , and 0.18 respectively; this study will contribute a better understanding towards Islamic tourism management in Aqaba city.
\end{abstract}

Keywords: Islamic attributes of destination, tourist satisfaction, destination loyalty, Aqaba, Jordan, SEM (Structural Equation Modeling)

\section{Introduction}

Today, tourism has become a major international asset and concern. Every country has a tourism ministry and a tourism high council. Every country counts each year the numbers of tourists, how much they spend and how many days and nights they stay in a particular place (Al-Amin, 2002). Tourism means the exchange of cultures and learn about the customs and traditions of the peoples, in the human while traveling to another country, it recognizes the culture and customs and traditions, and that deepens the ties between the peoples of the world, but the traveler and the tourist and can also be an ambassador for his country in the definition of culture and highlight the civilized image of the behavior of its members.

Religious tourism is that form that is exclusively or strongly motivated for religious reasons (Duman, 2012). One of the oldest types of tourism and a worldwide phenomenon of religious history, it can be differentiated into various forms. The short-term religious tourism is distinguished by excursions to nearby pilgrimage centers or religious conferences. The long-term describes visits of several days or weeks to national and international pilgrimage sites or conferences (Rinschede, 1992). Some of the definitions of the concept of Islamic tourism found in literature defined Islamic tourism that is all product development and marketing efforts designed for and directed at Muslims. Motivations are not always or entirely religious. Participants could be pursuing similar leisure experiences as non-Muslims, albeit within parameters set by Islam, and destinations are not necessarily locations where the shariah or full Islamic law is enacted (Zamani-Farahani \& Henderson, 2010).

Jordan are advertising "Islamic Tourism" worldwide to attract more Arab and Muslim tourists. In particular Jordan is promoting, among others, the shrines of Mu'tah (Al-Hamarneh, 2005). In Aqaba city, which is triggering a witness historically and Islamic civilizations and ancient nations that inhabited the city, facing many of the interested who would like to view this historical Islamic places that were constructed in the early centuries, including the Aqaba Castle and Islamic Ayla city.

The importance of this study in being a working knowledge of the concept of Islamic tourism and its importance as a 
kind of tourism has an impact on tourists in the target in the city of Aqaba tourist destination, through Islamic religious tourism is a modern tourist patterns; an important source to increase tourism income; diversify resources the tourism product marketing in Jordan; the uniqueness of the tourism product Jordanian Islamic religious tourism pattern at the level of the province; and specifies the number of Muslims in the world 2 billion, this tourism targeting this category. Further, due to the value of religious and situational and environmental and historical show by Aqaba city, has become tourist center attracts tourists from all over the world, and come this study in order to detect patterns and trends in the movement of Muslim tourists in the study area (Aqaba City); in addition to identify the constraints and services tourist and stand on the barriers to the growth of the tourism sector and its development in order to promote its role in the Jordanian national economy. The purpose of this study is to measure the motivating factors that influence destination loyalty among Islamic tourists.

\section{Literature Review}

Rahman (2014) focused on Islamic attributes; destination attributes quality of service, tourist's satisfaction, destination loyalty and demographic variables of the respondents. The primary objective of this study was to identify the motivational factors that influence Islamic tourists' satisfaction and revisit intention, and recommend and formulate strategies to develop the Islamic tourism industry in Malaysia. A survey instrument (PLS based SEM technique) was used to examine the relationships in the proposed model. The collected primary data $(n=198)$ from different tourist location in Kuala Lumpur was conducted to test the relationship between exogenous and endogenous construct expressed in the proposed structural model. The findings revealed that Islamic attributes and quality of service have significant relationship to Islamic tourist's satisfaction and destination loyalty, while destination attributes has not significant impact on it.

The study of Akyol \& Kilinc (2014) found individual characteristics such as age, gender, education and worldview have specific impacts on consumption. In addition to these individual characteristics, religion and belief have an impact on consumption and consumption habits to. Humans, at the same time as a consumer, religion and the belief guide them about how to live, how to consume, what to do or what not to do. For instance, in the context of Islam the notion of "Halal" shows its reflections on the field of marketing because of expectations such as Islamic lifestyle, hygiene, security and the services just for women the concept of "Halal Tourism" has become more demanded in the world and in Turkey. The main purpose of this study is to examine and define the concept of "Halal tourism" with its elements such as "halal hotels, halal transportation (halal airlines), halal food, halal tour packages and Halal finance." In this study, various examples of hotels', which offer services in the "Halal tourism" sector, web sites and their differentiating aspects in the tourism marketing were visually and textually analyzed and Halal holiday" are one of the most important factors that lead to the growth of the halal market.

Addressed the study (Battour \& Ismail, 2014), a total of 1,300 questionnaires were distributed in international hotels and tourism sites in four Malaysian cities: Kuala Lumpur, Kuala Terengganu, Penang, and Johor Bahru. The questionnaires were handed out in these cities following a convenience sampling approach. There was a scanning question on the cover page of the questionnaire to determine whether or not the tourist was Muslim or not. If the tourist was a Muslim, he/she was invited to proceed in filling in the questionnaire. The main purpose of this study are to test the relationship between tourism motivations and tourist satisfaction, and to test how 'Religion' moderates the relationship. The variable 'Religion' is represented by the availability of Islamic norms and practices which are relevant to tourism at the destination. And the results also showed that religion significantly moderates the relationship between pull motivation and tourist satisfaction. However, the moderating effect of religion on the relationship between push motivation and tourist satisfaction was not supported.

Duman \& Tosun (2010) aimed for two folds, is to propose a framework to better understand the term Islamic Tourism and "value" for its offering. Marketing scholars have long studied "perceived value" and proposed various conceptualizations of the term. However, further explorations are needed to broaden the concept as they should fit to the needs and expectations of Muslim consumers. Although Muslims make up one of the largest tourist markets in the world, perceived value of tourism offering oriented toward this market has not been clearly defined. Therefore, a framework to present an Islamic view to the concept constitute the first. The objective for that provide an overview of halal tourism market in Turkey. Current developments in the Turkish halal tourism market and the value of Turkish tourism offering are discussed in detail. Current issues and proposals for future studies are overviewed.

If we met to look at the study of (Tajzadeh, 2013), for the fast growth in the number of tourists and despite the great Muslim population worldwide (according to 2009 statistics, over 1.571 billion Muslims live in more than 100 countries around, the world making up $23 \%$ of the total world population. However, estimations show that by 2100 , Muslims will make up about $37 \%$ of total world population (Zamani-Farahani \& Henderson, 2010). In other words, although 
Islam is considered a major tourism market globally, while Muslim countries have been performing poorly in defining their roles and this has led to distorted views about Islam and Islamic values in non-Muslim countries. Therefore, it seems that by the time the present study is conducted, research on Islamic tourism is still in its infancy (Al- Hamarneh, 2005). The present theory attempts to present a framework on how to create value in an Islamic approach to tourism. This theory deals with all Muslims and supporters of Islam.

The aim of the study (Battour et al., 2011) was to explore Islamic religious attributes that may be important to Muslim travelers. In order to achieve this objective focus group discussions (FGD) were conducted and were followed up with interviews to explore opinions and travel experiences in more depth. This combination of the FGD and the interviews has its advantages in identifying a range of Islamic religious attributes from the FGD, and explore in depth, by conducting interviews using a relatively wide range of participants in order to discover more Islamic attributes and to check the conclusions with the FGD. The FGD and the interviews are research techniques pertaining to qualitative research. The aim of the FGD is to collect information through group interaction but the interview is considered an opportunity to discover new information from individuals. The success of marketing destinations for Muslim tourists could be guided by observing Islamic teachings in tourism activities. This study was a trial to explore which Islamic attributes of destinations could be used a base for tailoring Halal tourist packages.

While the study (Khaksari et al., 2014) highlights tourism development constraints with regard to religious perceptions in a religion- dominated country, Iran. The ruling class does not want to discount any of the fundamental social and cultural values in the process of preparing strategies for national tourism development plans. Countries such as Iran, concerned about potential negative influences of tourism development, de-emphasize potential positive economic impacts. In post-revolutionary Iran, tourism development and promotion follow unique, religiously-based strategies the current five-year development plan is a first step towards a transition to the recognition of the importance of tourism for economic development and improved international relations.

From this point of the study it is seeking to complete what was started by researchers. By focusing on the Tourism Islamic style in the Aqaba city and try to incorporate this style of tourism investment map in Aqaba city in particular and in Jordan in general for what for this type of tourist patterns is particularly important in product support and training in Jordan.

\section{Research Methodology}

This section provides the methodology applied in the current study. It consists of the research model, operational definitions of the study's independent, mediating and dependent variables; research hypotheses, besides data collection tool and research population and sample.

\subsection{Research Model and Hypotheses}

The elements of this research are established based on preceding literature, either theoretically or empirically. Indeed, this study used variables that are common in tourism management literature. Adapted from Battour et al. (2014), the current research considers four attitudes towards Islamic attributes of destination (the independent variable). These dimensions are worship facilities, halalness, alcohol \& gambling free, and Islamic morality; which were measured in the research questionnaire through six, five, two, and five items respectively. Also, both variables of tourist satisfaction and destination loyalty were adapted from Rahman (2014) and measured through five items each. Figure 1 represents a model for the study that shows the relationships among the research variables. 


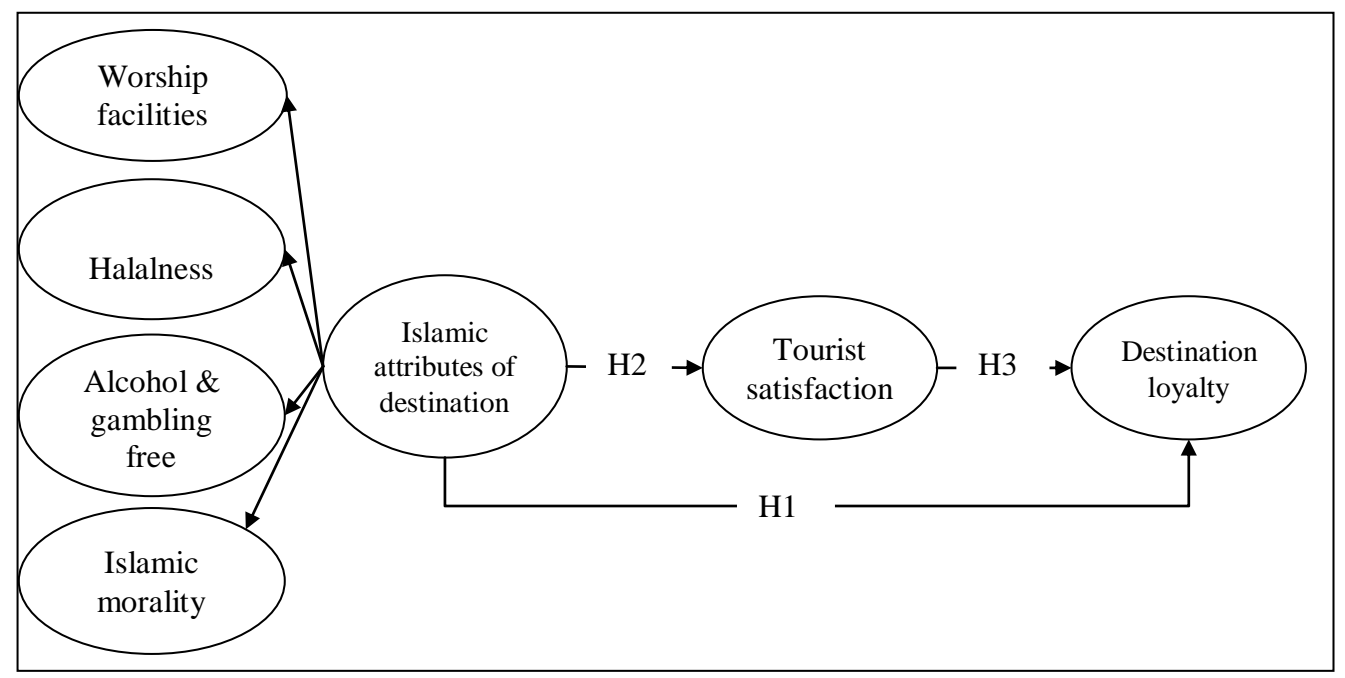

Figure 1. Research Model

H1: The Islamic attributes of destination directly and positively affect tourists' destination loyalty.

$\mathrm{H} 2$ : The Islamic attributes of destination directly and positively affect tourists' satisfaction.

H3: Tourists' satisfaction directly and positively affect tourists' destination loyalty.

\subsection{Population and Sampling}

Empirical data for this study was collected through paper-based survey in Aqaba city in Jordan. Specifically, a survey questionnaire was used to gather data for hypotheses testing from tourists. Before implementing the surveys, the instrument was reviewed by five lecturers who are specialized in the hotel management discipline in order to identify problems with wording, content, and question ambiguity. After some changes were made based on their suggestions, the modified questionnaire was piloted on five tourists who were visiting Aqaba. Based on the feedback of this pilot study, minor edits were introduced to the survey questions, and the questionnaires were distributed to the participants. As per ethics policies, all potential participants were briefed about the nature of the work and were requested to provide explicit approval. The population of this study consists of all muslim tourists in Aqaba located in Jordan. Thus, a judgment sampling technique was conducted. The sample size of this study was determined based on the rules of thumb for using SEM within AMOS 21 in order to obtain reliable and valid results. Kline (2010) suggested that a sample of 200 or larger is suitable for a complicated path model. Furthermore, after eliminating the incomplete surveys, our sample size 243 from tourists met the recommended guidelines of Kline (2010), Krejcie \& Morgan (1970) and Pallant (2005). The demographic data of the respondents are reported in Table 1.

Table 1. Description of the respondents' demographic profiles

\begin{tabular}{lccc}
\hline Category & Category & Frequency & Percentage\% \\
\hline Tourist's region & Europe & 40 & 16.5 \\
\cline { 2 - 4 } & Asia Pacific & 15 & 6.2 \\
\cline { 2 - 4 } & Americas & 36 & 14.8 \\
\cline { 2 - 4 } & Africa & 11 & 4.5 \\
\cline { 2 - 4 } & Middle East & 141 & 58.0 \\
\cline { 2 - 4 } Gender & Total & 243 & 100 \\
\cline { 2 - 4 } & Males & 161 & 66.3 \\
\cline { 2 - 4 } & Females & 82 & 33.7 \\
\hline Age & Total & 243 & 100 \\
\hline
\end{tabular}




\begin{tabular}{|c|c|c|c|}
\hline & 20 years - less than 25 & 43 & 17.7 \\
\hline & 25 years - less than 30 & 37 & 15.3 \\
\hline & 30 years - less than 40 & 82 & 33.7 \\
\hline & More than 40 years old & 70 & 28.8 \\
\hline & Total & 243 & 100 \\
\hline \multirow[t]{7}{*}{ Education level } & Less than high school & 9 & 3.7 \\
\hline & High school & 46 & 18.9 \\
\hline & Diploma & 36 & 14.8 \\
\hline & Bachelor & 120 & 49.4 \\
\hline & Master & 22 & 9.1 \\
\hline & Doctorate & 10 & 4.1 \\
\hline & Total & 243 & 100 \\
\hline \multirow{4}{*}{$\begin{array}{l}\text { Personal income }(\$) \\
\text { per month }\end{array}$} & Less than 500 & 77 & 31.7 \\
\hline & 500- less than 1000 & 97 & 39.9 \\
\hline & More than 1000 & 69 & 28.4 \\
\hline & Total & 243 & 100 \\
\hline
\end{tabular}

As indicated in Table 1, the demographic profile of the respondents for this study showed that they are typically males, most of them from the middle east, 30 years old and above, the majorities hold bachelor degree earning 500-less than 1000 \$ per month.

\section{Data Analysis and Results}

In order to explore the associations among Islamic attributes of destination, tourist satisfaction, and destination loyalty, in which these variables have been measured using 5-points Likert scale that varies between not at all important $=1$ and very important $=5$; reliability and validity analyses were conducted, descriptive analysis was used to describe the characteristic of sample and the respondent to the questionnaires besides the independent and dependent variables. Also, SEM analysis was employed to test the research hypotheses. Table 2 shows the measured constructs and the items measuring each construct.

Table 2. Constructs and measurement items

\section{Construct}

Worship Facilities (WF)

\section{Measurement Items}

WF1: Availability of Mosque (Masjid).

WF2: Availability of prayer facilities at tourism sites, airport, shopping malls, hotels, conference halls, parks.

WF3: The possibility of hearing the Azan to refer to the time of prayer.

WF4: Placement of Qibla direction (Qibla stickers/direction point towards

Makkah city) in your hotel room.

WF5: Provision of a copy of the Holy Qur'an in each hotel room.

WF6: Availability of water supply in toilets at tourism sites, airport, shopping mall, hotel, parks.

Halalness (HL)

HL1: Availability of Halal food at tourism sites, airport, shopping malls, hotels, parks, etc.

HL2: Availability of segregated Halal kitchen in hotels and restaurants.

HL3: Availability of segregated areas for women at beaches.

HL4: Availability of hotels with segregated swimming pools and gymnasium for men and women.

HL5: Ban porn recreational places of hotels.

Alcohol \& Gambling Free (AG) AG1: Banning of alcoholic drinks at public places (such as tourism sites, hotels, parks).

AG2: Banning of gambling activities at public places (such as tourism sites, 


\begin{tabular}{ll}
\hline & hotels, parks). \\
\hline Islamic Morality (IM) & IM1: Prevalence of Islamic dress code by hotel and restaurant staff. \\
IM2: Prevalence of Islamic dress code (e.g. Hijab) at public places. \\
IM3: Banning of sex by the hotel or place of accommodation. \\
IM4: Banning of some inappropriate behavior between the sexes (such as \\
kissing) in public places. \\
IM5: Banning views indecent films that appear on TV. \\
TS1: Spending enjoyable time with my travel companions. \\
TS2: Enhance communication with the local community. \\
TS3: Compared to my last visit to Aqaba, I stay longer period in the current \\
visit. "Don't answer the question if this is your first visit". \\
TS4: To fulfill my dream of visiting Jordan. \\
TS5: To satisfy the desire to be somewhere else. \\
DL1: I am willing to return to Aqaba city in the future. \\
DL2: I am willing to recommend friends and family the Aqaba city as a \\
tourist destination. \\
DL3: I have a wonderful idea about Aqaba as a tourist destination. \\
DL4: I feel that I am sincere to return to the Aqaba city as a tourist \\
destination. \\
DL5: I always return to the same places that I already had in Aqaba.
\end{tabular}

\subsection{Descriptive Analysis}

In order to describe the responses and thus the attitude of the respondents toward each question they were asked in the survey, the mean and the standard deviation were estimated. While the mean shows the central tendency of the data, the standard deviation measures the dispersion which offers an index of the spread or variability in the data (Pallant, 2005; Sekaran \& Bougie, 2013). In other words, a small standard deviation for a set of values reveals that these values are clustered closely about the mean or located close to it; a large standard deviation indicates the opposite. The level of each item was determined by the following formula: (highest point in Likert scale - lowest point in Likert scale) / the number of the levels used $=(5-1) / 5=0.80$, where 1-1.80 reflected by "very low", 1.81-2.60 reflected by "low", 2.61-3.40 reflected by "moderate", 3.41-4.20 reflected by "high", and 4.21-5 reflected by "very high". Then the items were being ordered based on their means. Tables 3 and 4 show the results.

Table 3. Overall mean and standard deviation of the study's variables

\begin{tabular}{clcccc}
\hline $\begin{array}{c}\text { Type of } \\
\text { Variable }\end{array}$ & Variables & Mean & Standard Deviation & Level & Order \\
\hline $\begin{array}{c}\text { Independent } \\
\text { Variable }\end{array}$ & Islamic Attributes of Destination & 4.00 & 0.88 & High & \\
\hline & Worship Facilities & 4.10 & 0.88 & High & 2 \\
\hline & Halalness & 4.07 & 1.01 & High & 3 \\
\hline & Alcohol \& Gambling Free & 4.22 & 1.18 & Very high & 1 \\
\hline $\begin{array}{c}\text { Mediating } \\
\text { Variable }\end{array}$ & Tourist's Satisfaction & 3.62 & 0.98 & High & 4 \\
\hline $\begin{array}{c}\text { Dependent } \\
\text { Variable }\end{array}$ & Destination Loyalty & 4.03 & 0.60 & High & \\
\hline
\end{tabular}

As presented in Table 3, data analysis results have shown that Islamic attributes of destination in Aqaba is applied to a high level in which the mean score is 4.00 . Further, alcohol \& gambling free, worship facilities, halalness, and Islamic morality do exist highly and respectively; besides both of tourist satisfaction and destination loyalty are applied to a greater extent. Table 4 demonstrates the mean, standard deviation, level, and order scores for items to each variable. 
Table 4. Mean and standard deviation of the study's variables

\begin{tabular}{|c|c|c|c|c|}
\hline Worship Facilities & Mean & SD & Level & Order \\
\hline Availability of Mosque (Masjid) & 4.35 & 1.14 & Very high & 2 \\
\hline $\begin{array}{l}\text { Availability of prayer facilities at tourism sites, airport, shopping malls, } \\
\text { hotels, conference halls, parks }\end{array}$ & 4.35 & 1.11 & Very high & 2 \\
\hline The possibility of hearing the Azan to refer to the time of prayer & 4.11 & 1.05 & High & 3 \\
\hline $\begin{array}{l}\text { Placement of Qibla direction (Qibla stickers/direction point towards } \\
\text { Makkah city) in your hotel room }\end{array}$ & 3.72 & 1.09 & High & 4 \\
\hline Provision of a copy of the Holy Qur'an in each hotel room & 3.50 & 1.14 & High & 5 \\
\hline $\begin{array}{l}\text { Availability of water supply in toilets at tourism sites, airport, shopping } \\
\text { mall, hotel, parks }\end{array}$ & 4.60 & 0.91 & Very high & 1 \\
\hline Halalness & Mean & SD & Level & Order \\
\hline $\begin{array}{l}\text { Availability of Halal food at tourism sites, airport, shopping malls, hotels, } \\
\text { parks, etc }\end{array}$ & 4.23 & 1.03 & Very high & 2 \\
\hline Availability of segregated Halal kitchen in hotels and restaurants & 3.87 & 1.24 & High & 4 \\
\hline Availability of segregated areas for women at beaches & 3.83 & 1.31 & High & 5 \\
\hline $\begin{array}{l}\text { Availability of hotels with segregated swimming pools and gymnasium for } \\
\text { men and women }\end{array}$ & 4.01 & 1.29 & High & 3 \\
\hline Ban porn recreational places of hotels & 4.42 & 1.16 & Very high & 1 \\
\hline Alcohol \& Gambling Free & Mean & SD & Level & Order \\
\hline $\begin{array}{l}\text { Banning of alcoholic drinks at public places (such as tourism sites, hotels, } \\
\text { parks) }\end{array}$ & 4.07 & 1.33 & High & 2 \\
\hline $\begin{array}{l}\text { Banning of gambling activities at public places (such as tourism sites, } \\
\text { hotels, parks) }\end{array}$ & 4.37 & 1.17 & Very high & 1 \\
\hline Islamic Morality & Mean & SD & Level & Order \\
\hline Prevalence of Islamic dress code by hotel and restaurant staff & 3.37 & 1.13 & Moderate & 4 \\
\hline Prevalence of Islamic dress code (e.g. Hijab) at public places & 3.12 & 1.22 & Moderate & 5 \\
\hline Banning of sex by the hotel or place of accommodation & 4.19 & 1.32 & High & 1 \\
\hline $\begin{array}{l}\text { Banning of some inappropriate behavior between the sexes (such as } \\
\text { kissing) in public places }\end{array}$ & 3.87 & 1.29 & High & 2 \\
\hline Banning a views indecent films that appear on TV & 3.58 & 1.37 & High & 3 \\
\hline Tourist's Satisfaction & Mean & SD & Level & Order \\
\hline Spending enjoyable time with my travel companions & 4.28 & 0.84 & Very high & 3 \\
\hline Enhance communication with the local community & 4.29 & 0.79 & Very high & 2 \\
\hline $\begin{array}{l}\text { Compared to my last visit to Aqaba, I stay longer period in the current } \\
\text { visit. "Don't answer the question if this is your first visit" }\end{array}$ & 3.38 & 1.05 & Moderate & 5 \\
\hline Am here in Aqaba to fulfill my dream of visiting Jordan & 3.92 & 0.93 & High & 4 \\
\hline Am here in Aqaba to satisfy the desire to be somewhere else & 4.31 & 1.03 & Very high & 1 \\
\hline Destination Loyalty & Mean & SD & Level & Order \\
\hline I am willing to return to Aqaba city in the future & 4.24 & 1.02 & Very high & 4 \\
\hline $\begin{array}{l}\text { I am willing to recommend friends and family the Aqaba city as a tourist } \\
\text { destination }\end{array}$ & 4.39 & 0.88 & Very high & 1 \\
\hline I have a wonderful idea about Aqaba as a tourist destination & 4.33 & 0.87 & Very high & 2 \\
\hline I feel that I am sincere to return to the Aqaba city as a tourist destination & 4.28 & 0.85 & Very high & 3 \\
\hline I always return to the same places that I already had in Aqaba & 3.83 & 1.15 & High & 5 \\
\hline
\end{tabular}




\subsection{Measurement Model}

Confirmatory factor analysis (CFA) was conducted to check the properties of the instrument items. Indeed, the measurement model indicates how latent variables or hypothetical constructs are assessed in terms of observed variables; and embodies the validity and reliability of the observed variables responses for the latent variables (Bagozzi \& Yi, 1988; Hair et al., 2006). Because the initial CFA model did not provide an acceptable fit, two items (Compared to my last visit to Aqaba, I stay longer period in the current visit. "Don't answer the question if this is your first visit"; and I always return to the same places that I already had in Aqaba) were eliminated to obtain a better fitting measurement model. The results of the revised CFA indicated that the chi-square $\left(\mathrm{x}^{2}\right)$ value of the model was 912.216, with 248 degrees of freedom ( $p<0.05$ ), which implies that the measurement did not fit the data well. The other model fit indices used for this study were the $\mathrm{x}^{2} / \mathrm{df}(912.216 / 248=3.21$; threshold less 3 for a serious viewpoint or less 5 for acceptable criteria), the Incremental Fit Index (IFI) of 0.93, Tucker- Lewis Index (TLI) of 0.91, Comparative Fit Index (CFI) of 0.93, the Goodness-of-Fit Index (GFI) of 0.91, the Adjusted Goodness-of-Fit Index (AGFI) of 0.90, the Normed Fit Index (NFI) of 0.94, the Root Mean Square Error of Approximation (RMSEA) of 0.049, and the Standardized Root Mean Square Residual (SRMR) of 0.046. Based on these fit indices, the measurement model appeared to fit the sample data well (Hair et al., 2010).

Table 5 shows the factor loadings, Cronbach alpha, composite reliability, and Average Variance Extracted (AVE) for the variables. All of the indicators of the factor loadings exceeded 0.50, thus constitute evidence of convergent validity (Bagozzi \& Yi, 1988; Creswell, 2009). Indeed, while the measurement reached convergent validity at the item level because all of the factor loadings went above 0.50 , all of the composite reliability values exceeded 0.60 , demonstrating a high level of internal consistency for the latent variables. In addition, since each value of AVE exceeded 0.50 (Bagozzi \& Yi, 1988; Hair et al., 2006), the convergent validity was proved.

Table 5. Properties of the final measurement model

\begin{tabular}{|c|c|c|c|c|}
\hline $\begin{array}{l}\text { Constructs and } \\
\text { Indicators }\end{array}$ & $\begin{array}{c}\text { Factor } \\
\text { Loadings }\end{array}$ & $\begin{array}{c}\text { Cronbach } \\
\text { Alpha }\end{array}$ & $\begin{array}{l}\text { Composite } \\
\text { Reliability }\end{array}$ & AVE \\
\hline Worship Facilities & & 0.899 & 0.84 & 0.59 \\
\hline WF1 & 0.942 & & & \\
\hline WF2 & 0.955 & & & \\
\hline WF3 & 0.839 & & & \\
\hline WF4 & 0.733 & & & \\
\hline WF5 & 0.622 & & & \\
\hline WF6 & 0.599 & & & \\
\hline Halalness & & 0.892 & 0.82 & 0.53 \\
\hline HL1 & 0.734 & & & \\
\hline HL2 & 0.757 & & & \\
\hline HL3 & 0.752 & & & \\
\hline HL4 & 0.829 & & & \\
\hline HL5 & 0.866 & & & \\
\hline $\begin{array}{l}\text { Alcohol \& Gambling } \\
\text { Free }\end{array}$ & & 0.880 & 0.85 & 0.55 \\
\hline AG1 & 0.882 & & & \\
\hline AG2 & 0.898 & & & \\
\hline Islamic Morality & & 0.836 & 0.82 & 0.57 \\
\hline IM1 & 0.636 & & & \\
\hline IM2 & 0.577 & & & \\
\hline IM3 & 0.879 & & & \\
\hline IM4 & 0.794 & & & \\
\hline IM5 & 0.565 & & & \\
\hline
\end{tabular}




\begin{tabular}{lllll}
\hline Tourist's Satisfaction & & 0.618 & 0.79 & 0.55 \\
\hline TS1 & 0.555 & & & \\
\hline TS2 & 0.708 & & & \\
\hline TS4 & 0.509 & & 0.84 & 0.54 \\
\hline TS5 & 0.503 & 0.861 & & \\
\hline Destination Loyalty & & & & \\
\hline DL1 & 0.651 & & & \\
\hline DL2 & 0.817 & & & \\
\hline DL3 & 0.857 & 0.826 & & \\
\hline DL4 & & & & \\
\hline
\end{tabular}

Also, as noticed from Table 6, all of the intercorrelations between pairs of constructs were less than the square root of the AVE estimates of the two constructs, providing discriminant validity (Hair et al., 2006). Consequently, the measurement results indicating that this study had adequate levels of convergent and discriminant validity.

Table 6. AVE and square of correlations between constructs

\begin{tabular}{lllllll}
\hline Constructs & WF & HL & AG & IM & TS & DL \\
\hline WF & 0.59 & & & & & \\
\hline HL & 0.37 & 0.53 & & & & \\
\hline AG & 0.35 & 0.37 & 0.55 & & & \\
\hline IM & 0.43 & 0.30 & 0.41 & 0.57 & & \\
\hline TS & 0.29 & 0.38 & 0.22 & 0.26 & 0.55 & \\
\hline DL & 0.21 & 0.22 & 0.28 & 0.33 & 0.29 & 0.54 \\
\hline
\end{tabular}

Note: Diagonal elements are the average variance extracted for each of the six constructs. Off-diagonal elements are the squared correlations between constructs.

\subsection{Structural Model}

The SEM analysis revealed that the Islamic attributes of destination directly, positively, and significantly affected the tourists' destination loyalty $(\beta=0.220, t=4.112, p=0.000)$; thus, $\mathrm{H} 1$ was accepted. The Islamic attributes of destination found to be directly and positively impacted tourists' satisfaction $(\beta=0.143, \mathrm{t}=3.233, \mathrm{p}=0.001)$; consequently, $\mathrm{H} 2$ was accepted. Also, tourists' satisfaction directly, positively, and significantly affected tourists' destination loyalty $(\beta=0.230, \mathrm{t}=3.017, \mathrm{p}=0.003)$; thus, $\mathrm{H} 3$ was accepted. Furthermore, the coefficient of determination $\left(\mathrm{R}^{2}\right)$ for the research endogenous variables for tourists' satisfaction, and tourists' destination loyalty were 0.41 , and 0.18 respectively, which indicates that the model does moderately account for the variation of the proposed model.

\section{Discussion and Conclusions}

The purposes of this paper were to propose a conceptual framework for Islamic tourism concept and comment on Aqaba Islamic tourism industry. Our analysis of previous literature shows that there seems to be an ambiguity on the definition of Islamic tourism concept. Commentators and authors fail to agree on the definition and the purview of the concept. In this paper, we propose an inspirational approach to the concept and argue that Islamic tourism is more of a philosophical discussion. Moreover, clearly the word "Islamic" provide the question of "what is Islamic and what is not?" so, we come up with a definition that takes Islamically acceptable inspirations as the reference point. We also propose to use the title "Halal" to represent the economy and the sector where halal goods and services give to the markets. Briefly, Islamic tourism describe the demand side (i.e. participant and his/her motivations) while halal tourism represent the supply side with districts, goods and services offered for consumption. Islam and tourism are multidisciplinary areas. Therefore, a united effort is needed to deepen the discussion on Islam and tourism. Academicians from Islam and tourism as well as other related areas should get together and comprise an edited book to discuss different sides of the concept and offer conceptualizations from their own perspectives. There is too much 
information pollution about Islam, Muslims and Islamic way of life today and proper academic work will diminish the effects of this pollution. On the practitioners' side, certification and accreditation practices are important to provide standard, high quality halal goods and services for market.

An additional conclusion related to 'Halalness', which was found to be most necessary Islamic attribute could help destination marketers to satisfy Muslim tourists By give Halal 'Islamic' products/services, a specific destination may be able to separate itself from other destinations For example, the availability of Halal food in hotels and restaurants could show a high priority for Muslim tourists in destination choice. So, when marketers promote a destination to Muslim tourists, promotional movement should focus more on the availability of Halal food more, and the availability of isolated entertainments.

It is familiar that Muslim customers create a broad market, which has special conditions and culture, which cannot be forgotten. In reply to these, 'worship facilities', represent important elements identified by the current study so could be used by destination marketers as a way to satisfy Muslim tourist needs on their vacation. For example, the provision of maps indicating the locations of mosques/ prayer facilities could be made available in areas, such as tourist information centers, airports, hotels and parks to please and satisfy Muslim tourists. Providing worship facilities for Muslim tourists may motivate them to travel to a specific destination. However, the other factor: 'alcohol- and gambling-free zones' identified by this study might create a challenge to destination marketers in Muslim countries, which, at the same time, are also trying to satisfy the non-Muslim tourist's needs. Therefore, managers might be encouraged to design creative programs to build the unique characteristics of tourist products to satisfy this attribute. For example, the hotel might design a special section for those wishing to drink alcohol because Muslims prefer there not to be any public consumption of alcoholic drinks and gambling activities. So, Muslim tourists prefer alcoholic drinks not to be provided in the hotel room refrigerator, if not requested. This study provides some new insights into the impact of IADs on in general tourist satisfaction; however, the results reported here should be interpreted in the light of certain limitations that suggest further possibilities for empirical study. The main limitation concerns the environment of the study (Aqaba), which applies constraints on the generalizability of the results to other countries. Therefore, no claim can be made for the generalizability of the findings beyond these contexts.

In addition, scholars (e.g. Masa'deh et al. 2008; Hunaiti et al., 2009; Masa'deh \& Kuk, 2009; Alshurideh et al., 2012; Hajir et al., 2015; Kannan \& Gharibeh, 2013; Masa'deh \& Shannak, 2012; Masa'deh et al. 2013; Masa'deh et al. 2015a, 2015b, 2015c; Masa'deh et al. 2017; Obeidat et al., 2012, 2016; Shannak \& Alkour, 2012; Tarhini et al., 2015a, 2015b) emphasize the need for large corporations to integrate their Information Technology (IT) systems with their Knowledge Management (KM) strategies and processes in order to survive in their highly competitive business environments, which in turn could accelerate the managerial decisions as well. Also, several researchers consider the information systems and in particular the information technology (IT) and its flexibility as an enabler to achieve the desired competitive advantages, and as a crucial support to operational and strategic business decisions (Al Azmi et al., 2012; Alenezi et al., 2015; Alkalha et al., 2012; Almajali \& Tarhini, 2016; Altamony et al., 2012; Kateb et al., 2015; Maqableh \& Karajeh, 2014a, 2014b; Masa'deh, 2012, 2013a, 2013b; Masa'deh et al., 2016; Obeidat, et al., 2013; Shannak et al., 2010, 2012a, 2012b; Tarhini et al., 2016; Vratskikh et al., 2016); thus further research is required to examine the role of such IT applications in enhancing the managerial decisions regarding Islamic attributes of destination, tourist satisfaction, and destination loyalty.

\section{References}

Abbasi, M. S., Elyas, T., \& Shah, F. (2015). Impact of individualism and collectivism over the individual's technology acceptance behaviour: A multi-group analysis between Pakistan and Turkey. Journal of Enterprise Information Management, 28(6), 747-768. https://doi.org/10.1108/JEIM-12-2014-0124

Akyol, M., \& Kilinc, O. (2014). Internet and Halal Tourism Marketing. International Periodical for the Languages, Literature and History of Turkish or Turkic, 171-186.

Al Azmi, N., Al-Lozi, M., Al-Zu'bi, Z., Dahiyat, S., \& Masa'deh, R. (2012). Patients Attitudes toward Service Quality and its Impact on their Satisfaction in Physical Therapy in KSA Hospitals. European Journal of Social Sciences, 34(2), 300-314.

Al-Amin, H. (2002). Religious Tourism in Islamic Heritage. Islamic Tourism, 2, 32-36.

Al-Badi, A., Tarhini, A., \& Al-Kaaf, W. (2017). Financial Incentives for Adopting Cloud Computing in Higher Educational Institutions. Asian Social Science, 13(4), 162-174. https://doi.org/10.5539/ass.v13n4p162

Al-Badi, A., Tarhini, A., \& Al-Sawaei, S. (2017). Utilizing Social Media to Encourage Domestic Tourism in Oman. 
International Journal of Business and Management, 12(4), 84-94. https://doi.org/10.5539/ijbm.v12n4p84

Al-Badi, A. H., \& Al-Qayoudhi, W. S. (2014). Adoption of social networks in business: Study of users and potential users in Oman. The International Business \& Economics Research Journal (Online), 13(2), 401-415.

Al-Dmour, H., Al-Madani, S., Alansari, I., \& Al-Dmour, R. (2016). Factors Affecting the Effectiveness of Cause-Related Marketing Campaign: Moderating Effect of Sponsor-Cause Congruence. International Journal of Marketing Studies, 8(5), 114-127. https://doi.org/10.5539/ijms.v8n5p114

Al-Dmour, R., \& Obeidat, B. (2015). Strategic IT-Business Alignment as Managers' Explorative and Exploitative Strategies. European Scientific Journal, 11(7), 437-457.

Alenezi, H., Masa'deh, R. Alalwan, A., \& Al-Qirim, N. (2017). Factors Affecting e-Government Adoption in Kuwait: A Qualitative study. Electronic Journal of e-Government, 15(2), 84-102.

Alenezi, H., Tarhini, A., \& Masa'deh, R. (2015). Investigating the Strategic Relationship between Information Quality and E-Government Benefits: A Literature Review. International Review of Social Sciences and Humanities, 9(1), 33-50.

Al-Hamarneh, A. (2005). New Tourism Trends in the Arab World. Islamic Tourism, 16(2), 50-54.

Alkalha, Z., Al-Zu'bi, Z., Al-Dmour, H., \& Alshurideh, M. (2012). Investigating the Effects of Human Resource Policies on Organizational Performance: An Empirical Study on Commercial Banks Operating in Jordan. European Journal of Economics, Finance and Administrative Sciences, 51, 44-64.

Allam, M., \& Elyas, T. (2016). Perceptions of Using Social Media as an ELT Tool among EFL Teachers in the Saudi Context. English Language Teaching, 9(7), 1-9. https://doi.org/10.5539/elt.v9n7p1

Almajali, D., \& Tarhini, A. (2016). Antecedents of ERP Systems Implementation Success: A Study on Jordanian Healthcare Sector. Journal of Enterprise Information Management, 29(4), 549-565.

Al-Mukhaini, E. M., Al-Qayoudhi, W. S., \& Al-Badi, A. H. (2014). Adoption of social networking in education: A study of the use of social networks by higher education students in Oman. Journal of International Education Research, 10(2), 143-155. https://doi.org/10.19030/jier.v10i2.8516

Al-Qirim, M., Rouibah, K., Serhani, M. A., Yammahi, A. R., \& Yammahi, M. A. (2017). Towards a Personality Understanding of Information Technology Students and their IT Learning in UAE University. Education and Information Technologies, 1-12. https://doi.org/10.1007/s10639-017-9578-1

Al-Qirim, N., Rouibah, K., Serhani, M. A., Yammahi, A. R., \& Yammahi, M. A. (2017). Learning Orientations of IT Higher Education Students in UAE University. Education and Information Technologies, 1-14. https://doi.org/10.1007/s10639-017-9589-y

Al-Qirim N., Tarhini, A., Rouibah, K. (2017). Determinants of Big Data Adoption and Success. In International Conference on Communications and Future Internet (ICCFI 2017). Jeju Island, South Korea, 10-13 August.

Alqahtani, M. A., Al-Badi, A. H., \& Mayhew, P. J. (2012). The Enablers and Disablers of E-Commerce: Consumers' Perspectives. The Electronic Journal of Information Systems in Developing Countries, 54(1), 1-25.

Alrowwad, A., Obeidat, B.Y., \& Aqqad, N. (2017). The impact of transformational leadership on organizational performance via the mediating role of corporate social responsibility: A structural equation modeling approach. International Business Research, 10(1), 199-221. https://doi.org/10.5539/ibr.v10n1p199

Alshurideh, M., Masa'deh, R., \& Alkurdi, B. (2012). The Effect of Customer Satisfaction on Customer Retention in the Jordanian Mobile Market: An Empirical Investigation. European Journal of Economics, Finance and Administrative Sciences, 47, 69-78.

Altamony, H., Alshurideh, M., \& Obeidat, B. (2012). Information Systems for Competitive Advantage: Implementation of an Organizational Strategic Management Process. Proceedings of the 18th IBIMA Conference on Innovation and Sustainable Economic Competitive Advantage: From Regional Development to World Economic, Istanbul, Turkey, 9th-10th May.

Altamony, H., Al-Salti, Z., Gharaibeh, A., \& Elyas, T. (2016). The relationship between Change Management Strategy and Successful Enterprise Resource Planning (ERP) Implementations: A Theoretical Perspective. International Journal of Business Management and Economic Research, 7(4), 690-703

Bagozzi, R., \& Yi, Y. (1988). On the Evaluation of Structural Evaluation Models. Journal of the Academy of Marketing Science, 16(1), 74-94. https://doi.org/10.1007/BF02723327 
Battour, M., \& Ismai, M. (2014). The Role of Destination Attributes in Islamic Tourism. SHS web of conferences, 12(3), 11-23. https://doi.org/10.1051/shsconf/20141201077

Battour, M., Battor, M., \& Bhatti, M. (2014). Islamic Attributes of Destination: Construct Development and Measurement Validation, and Their Impact on Tourist Satisfaction. International Journal of Tourism Research, 16, 556-564. https://doi.org/10.1002/jtr.1947

Battour, M., Ismai, M., \& Battor, M. (2011). The Impact of Destination Attributes on Muslim Tourist's Choice. International Journal of Tourism Research, 13, 527-540. https://doi.org/10.1002/jtr.824

Bisharat, H., Obeidat, B.Y., Alrowwad, A., Tarhini, A., \& Mukattash, I. (2017). The Effect of Human Resource Management Practices on Organizational Commitment in Chain Pharmacies in Jordan. International Journal of Business and Management, 12(1), 50-67. https://doi.org/10.5539/ijbm.v12n1p50

Creswell, J. (2009). Research Design: Qualitative, Quantitative, and Mixed Methods Approaches (3rd ed.). Thousand Oaks: Sage Publications.

Duman, T. (2012). The Value of Islamic Tourism: Perspectives from the Turkish Experience. Islam and Civilisational Renewal (ICR), 3(4).

Duman, T., \& Tosun, C. (2010). Current Developments in Turkish Tourism. An International Journal of Tourism and Hospitality Research, 21(1), 5-9. https://doi.org/10.1080/13032917.2010.9687086

El-Masri, M., \& Tarhini, A. (2015). A Design Science Approach to Gamify Education: From Games to Platforms. Twenty-Third European Conference on Information Systems (ECIS), Münster, Germany. 26-29 May 2015.

El-Masri, M., \& Tarhini, A. (2017). Factors affecting the adoption of e-learning systems in Qatar and USA: Extending the Unified Theory of Acceptance and Use of Technology 2 (UTAUT2). Educational Technology Research and Development, 65(3), 743-763. https://doi.org/10.1007/s11423-016-9508-8

El-Masri, M., Orozco, J., Tarhini, A., \& Tarhini, T. (2015). The Impact of IS-Business Alignment Practices on Organizational Choice of IS-Business Alignment Strategies. The 19th Pacific Asia Conference on Information Systems (PACIS 2015), Paper 215, Singapore, 6-9 July 2015.

Elyas, T. \& Picard, P. (2012). Teaching and Moral Tradition in Saudi Arabia: A Paradigm of Struggle or Pathway towards Globalization?. Procedia - Social and Behavioral Sciences, 41, 1083-1086.

Fedai, L., Daglı, G., Altınay, Z. \& Altınay, F. (2017). The examination of occupational burnout and job satisfaction of the physical education teachers. International Journal of Economic Perspectives, 11(1), 12-26.

Hair, J., Black, W., Babin, B., Anderson, R., \& Tatham, R. (2006). Multivariate Data Analysis (6th ed.). New Jersey: Prentice-Hall.

Hair, J., Black, W., Babin, B., Anderson, R., \& Tatham, R. (2010). Multivariate Data Analysis (7th ed.). New Jersey: Prentice-Hall.

Hajir, J., Obeidat, B., \& Al-dalahmeh, M. (2015). The Role of Knowledge Management Infrastructure in Enhancing Innovation at Mobile Telecommunication Companies in Jordan. European Journal of Social Sciences, 50(3), 313-330.

Hamoud, M., Akour, M. A., \& Al-Salti, Z. (2016). Developing the Main Knowledge Management Process via Social Media in the IT Organisations: A Conceptual Perspective. International Journal of Business Administration, 7(5), 49-64.

Hassouna, M., Elyas, T., \& Abou Trab, M. S. (2015). Customer Churn in Mobile Markets: A Comparison of Techniques. International Business Research, 8(6), 224-237. https://doi.org/10.5539/ibr.v8n6p224

Hussian, A., Elyas, T., \& Nasseef, O. (2013). Research Paradigms: A Slippery Slope for Fresh Researchers. Life Science Journal, 10(4), 2374-2381.

Hunaiti, Z., Mansour, M., \& Al-Nawafleh, A. (2009). Electronic Commerce Adoption Barriers in Small and Medium-Sized Enterprises (SMEs) in Developing Countries: The Case of Libya. IBIMA Business Review, 2(5), $37-45$.

Kanaan, R., \& Gharibeh, A. (2013). The Impact of Knowledge Sharing Enablers on Knowledge Sharing Capability: An Empirical Study on Jordanian Telecommunication Firms. European Scientific Journal, 9(22), 237-258.

Kateb, M., Swies, R., Obeidat, B., \& Maqableh, M. (2015). An Investigation on the Critical Factors of Information 
System Implementation in Jordanian Information Technology Companies. European Journal of Business and Management, 7(36), 11-28.

Khaksari, A., Lee, J., \& Lee, C. (2014). Religious Perceptions and Hegemony on Tourism Development: The Case of the Islamic Republic of Iran. International Journal of Tourism Research, 16, 97-103.

Kline, R. (2010). Principles and Practice of Structural Equation Modeling. The Guilford Press.

Mahadeen, B., Al-Dmour, R., \& Obeidat, B. Y. (2016). Examining the effect of the Organization's Internal Control System on Organizational Effectiveness: A Jordanian empirical study. International Journal of Business Administration, 7(6), 22-41. https://doi.org/10.5430/ijba.v7n6p22

Maqableh, M., \& Karajeh, H. (2014a). Job Scheduling for Cloud Computing Using Neural Networks. Communications and Network, 6(3), 191. https://doi.org/10.4236/cn.2014.63021

Maqableh, M., \& Karajeh, H. (2014b). A Theoretical Perspective on the Relationship between Leadership Development, Knowledge Management Capability, and Firm Performance. Asian Social Science, 10(6), 128.

Masa'deh, R. (2013). The Impact of Information Technology Infrastructure Flexibility on Firm Performance: An Empirical Study of Jordanian Public Shareholding Firms. Jordan Journal of Business Administration, 204-224.

Masa'deh, R., \& Kuk, G. (2009). Antecedents and Intermediaries between Strategic Alignment and Firm Performance. Conference of the Academy of Management Annual Meeting (AOM), Illinois, Chicago, USA.

Masa'deh, R., Gharaibeh, A., Maqableh, M., \& Karajeh, H. (2013a). An Empirical Study of Antecedents and Outcomes of Knowledge Sharing Capability in Jordanian Telecommunication Firms: A Structural Equation Modeling Approach. Life Science Journal, 10(4), 2284-2296.

Masa'deh, R., Hunaiti, Z., \& Bani Yaseen, A. (2008). An Integrative Model Linking IT-Business Strategic Alignment and Firm Performance: The Mediating Role of Pursuing Innovation and Knowledge Management Strategies. Communications of the International Business Information Management Association (IBIMA) Journal, 2(24), 180-187.

Masa'deh, R., Shannak, R., \& Maqableh, M. (2013b). A Structural Equation Modeling Approach for Determining Antecedents and Outcomes of Students' Attitude toward Mobile Commerce Adoption. Life Science Journal, $10(4), 2321-2333$.

Masa'deh, R., Tayeh, M., Al-Jarrah, I., \& Tarhini, A. (2015c). Accounting vs. Market-based Measures of Firm Performance Related to Information Technology Investments. International Review of Social Sciences and Humanities, 129-145.

Masa'deh, R. (2012). The Impact of Management Information Systems (MIS) on Quality Assurance (QA): A Case Study in Jordan. International Journal of Information, Business, and Management, 93-110.

Masa'deh, R., \& Shannak, R. (2012). Intermediary Effects of Knowledge Management Strategy and Learning Orientation on Strategic Alignment and Firm Performance. Research Journal of International Studies, 112-128.

Masa'deh, R., Gharaibeh, A., Tarhini, A., \& Obeidat, O. (2015a). Knowledge Sharing Capability: A Literature Review. In Fourth Scientific \& Research Conference on New Trends in Business, Management and Social Sciences, Istanbul, Turkey, 19-20 September 2015 (pp. 1-16). https://doi.org/10.2139/ssrn.2696924

Masa'deh, R., Obeidat, B., \& Tarhini, A. (2016). A Jordanian Empirical Study of the Associations among Transformational Leadership, Transactional Leadership, Knowledge Sharing, Job Performance, and Firm Performance: A Structural Equation Modelling Approach. Journal of Management Development, 35(5), 681-705. https://doi.org/10.1108/JMD-09-2015-0134

Masa'deh, R., Obeidat, B., Al-Dmour, R., \& Tarhini, A. (2015b). Knowledge Management Strategies as Intermediary Variables between IT-Business Strategic Alignment and Firm Performance. European Scientific Journal, 11(7), 344-368

Masa'deh, R., Shannak, R., Maqableh, M., \& Tarhini, A. (2017). The Impact of Knowledge Management on Job Performance in Higher Education: The Case of the University of Jordan. Journal of Enterprise Information Management, 30(2), 244-262. https://doi.org/10.1108/JEIM-09-2015-0087

Nassar, B., \& Arzoky, M. (2015). An Empirical Analysis of the Seasonal Patterns in Aggregate Directors' Trades. International Journal of Economics and Finance, 7(9), 59-84. https://doi.org/10.5539/ijef.v7n9p59

Obeidat, B. Y., Hashem, L., Alansari, I., \& Al-Salti, Z. (2016). The Effect of Knowledge Management Uses on Total 
Quality Management Practices: A Theoretical Perspective. Journal of Management and Strategy, 7(4), 18-29.

Obeidat, B., Al-Suradi, M., \& Tarhini, A. (2016). The Impact of Knowledge Management on Innovation: An Empirical Study on Jordanian Consultancy Firms. Management Research Review, 39(10), 1214-1238.

Obeidat, B., El-Rimawi, S., Maqableh, M., \& Al-Jarrah, I. (2013). Evaluating the Profitability of the Islamic Banks in Jordan. European Journal of Economics, Finance and Administrative Sciences, 56, 27-36.

Obeidat, B., Sweis, R., Zyod, D., \& Alshurideh, M. (2012). The Effect of Perceived Service Quality on Customer Loyalty in Internet Service Providers in Jordan. Journal of Management Research, 4(4), 224-242.

Obeidat, B.Y., Al-Sarayrah, S., Al-Salti, Z., \& Sweis, R. (2016). Cultural Influence on Strategic Human Resource Management Practices: A Jordanian case study. International Business Research, 9(10), 94-114.

Obeidat, B.Y., Tarhini, A., \& Aqqad, N. (2017). The impact of intellectual capital on innovation via the mediating role of knowledge management: A structural equation modeling approach. International Journal of Knowledge Management Studies, 8(2), 15-33.

Orozco, J., Tarhini, A., Masa'deh, R., \& Tarhini, T. (2015). A framework of IS/business alignment management practices to improve the design of IT Governance architectures. International Journal of Business and Management, 10(4), 1-12. https://doi.org/10.5539/ijbm.v10n4p1

Pallant, J. (2005). SPSS Survival Manual: A Step Guide to Data Analysis Using SPSS for Windows Version 12. Chicago, Illinois: Open University Press.

Rahman, M. (2014). Motivating Factors of Islamic Tourist's Destination Loyalty: An Empirical Investigation in Malaysia. Journal of Tourism and Hospitality Management, 2(1), 63-77.

Rinschede, G. (1992). Forms of Religious Tourism. Annals of Tourism Research, 19(1), 51-67.

Sekaran, U., \& Bougie, R. (2013). Research Methods for Business: A Skill-Building Approach (6th ed.). New York: Wiley.

Shannak, R., \& Akour, M. (2012). Knowledge Management Strategy Building: Literature Review. European Scientific Journal, 8(15), 143-168.

Shannak, R., Obeidat, B., \& Masa'deh, R. (2012b). Culture and the Implementation Process of Strategic Decisions in Jordan. Journal of Management Research, 4(4), 257-281. https://doi.org/10.5296/jmr.v4i4.2160

Tajzadeh, N. (2013). Value Creation in Tourism: An Islamic Approach. International Research Journal of Applied and Basic Sciences, 4(5), 1252-1264.

Tarhini, A., Al-Badi, A., Almajali, M., \& Alrabayaah, S. H. (2017). Factors influencing employees' Intention to use Cloud Computing. Journal of Management \& Strategy, 8(2), 47-62. https://doi.org/10.5430/jms.v8n2p47

Tarhini, A., Elyas, T., Akour, M. A., \& Al-Salti, Z. (2016). Technology, Demographic Characteristics and E-Learning Acceptance: A Conceptual Model Based on Extended Technology Acceptance Model. Higher Education Studies, 6(3), 72-89. https://doi.org/10.5539/hes.v6n3p72

Tarhini, A., El-Masri, M., Ali, M., \& Serrano, A. (2016). Extending the UTAUT model to understand the customers' acceptance and use of internet banking in Lebanon: A structural equation modeling approach. Information Technology and People, 29(4), 830-849. https://doi.org/10.1108/ITP-02-2014-0034

Tarhini, A., Arachchilage, N., \& Abbasi, M. (2015). A Critical Review of Theories and Models of Technology Adoption and Acceptance in Information System Research. International Journal of Technology Diffusion, 6(4), 58-77. https://doi.org/10.4018/IJTD.2015100104

Tarhini, A., Mgbemena, C., AbouTrab, M.S., \& Masa'deh, R. (2015). User Adoption of Online Banking in Nigeria: A Qualitative study. Journal of Internet Banking and Commerce, 20(3), 1-8.

Tarhini, A., Mohammed, A., \& Maqableh, M. (2016). Modeling Factors Affecting Student's Usage Behaviour of E-Learning Systems in Lebanon. International Journal of Business and Management, 11(2), 299-314.

Vratskikh, I., Al-Lozi, M., \& Maqableh, M. (2016). The Impact of Emotional Intelligence on Job Performance via the Mediating Role of Job Satisfaction. International Journal of Business and Management, 69-91. https://doi.org/10.5539/ijbm.v11n2p69

Zamani-Farahani, H., \& Henderson, J. (2010). Islamic Tourism and Managing Tourism Development in Islamic Societies: The Cases of Iran and Saudi Arabia. International Journal of Tourism Research, 12(1), 79-89. 